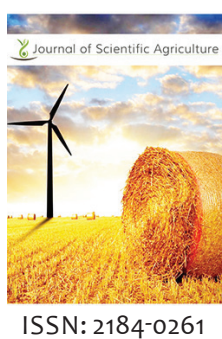

Received: April 21, 2018 Accepted: June 10, 2018 Published: June 24, 2018

*Corresponding Author: Tushar Vilasrao Desale Email: tush.desale13@gmail.com

\section{Effect of calcium hydroxide and neem products on paddy during storage}

\author{
Tushar Vilasrao Desale*, Minali Masih, Genitha Immanuel \\ Department of Agricultural Process and Food Engineering, S.H.U.A.T.S, Allahabad, Uttar Pradesh, India.
}

\section{INTRODUCTION}

Rice is a staple food in many countries including India. Indian rice production is of leading role in economy. The top 10 largest producer states of rice are West Bengal, Uttar Pradesh, Andhra Pradesh, Punjab, Tamil Nadu, Bihar, Chhattisgarh, Odisha, Assam, and Karnataka. Rice production is 72 MMT in India in the year 2015-16. In 2014-15, the Indian consumption of rice is $76.1 \mathrm{~kg}$ per capita [1-3].

Neem (Azadirachta indica) is considered as a native plant to Indian sub-continent. Neem is having many medicinal uses [4]. Neem products are used as neem insecticide, neem pesticide, neem pest fumigant, neem fertilizer, neem manure, neem compost, neem urea coating agent and neem soil conditioner [5].

Calcium hydroxide is usually known as lime, and is inorganic in nature with a chemical formula of $\mathrm{Ca}(\mathrm{OH})_{2}$.

In India, a large quantity of food grain is stored in villages in different traditional storage structures and containers [6]. The post harvest losses of paddy is rapidly increasing due to lack proper storage techniques in India and available storage techniques has high cost because of synthetic chemical usage. Solving all these problems we want to develop cheaper storage techniques by using neem products which is easily available in our country. This research was conducted to study the effect of different levels of $\mathrm{CaOH}+\mathrm{NEEM}$ on paddy during storage.

\section{MATERIALS AND METHODS}

The study was done at seed processing plant, Sam Higginbottom University of Agriculture Technology and Sciences, Allahabad."

\section{Material Required}

Neem leaves as shown in Figure 1, Neem seed kernel as shown in Figure 2, Calcium hydroxide in powder form as shown in Figure 3 and Gyratory shaker. Neem leaves selection done by mature plant leaves were collected from the forestry research field of school of forestry, SHUATS, Allahabad, India. Leaves were washed by tap water to discard all the impurities attached with them. They were shade dried for $48 \mathrm{~h}$ at room temperature. After that the leaves were dried in sun for 8 hours.

\section{Methods \\ Preparation of Neem aqueous extract}

In this study neem extract was prepared by mechanical extraction method from neem leaves. Neem aqueous extract was prepared by submerging the leaves in water for $48 \mathrm{~h}$ and after that neem aqueous solution shaking was done by wooden plank for $20 \mathrm{~min}$. The neem extract was separated by normal 


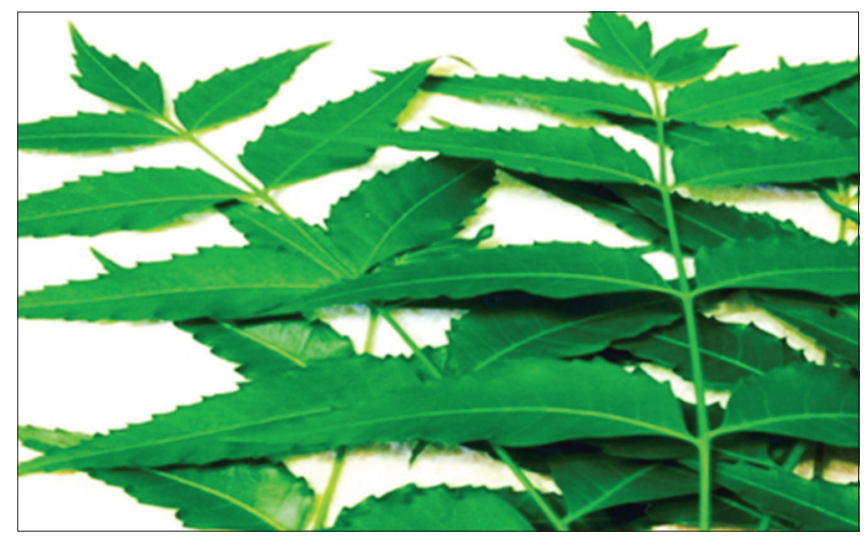

Figure 1: Neem leaves

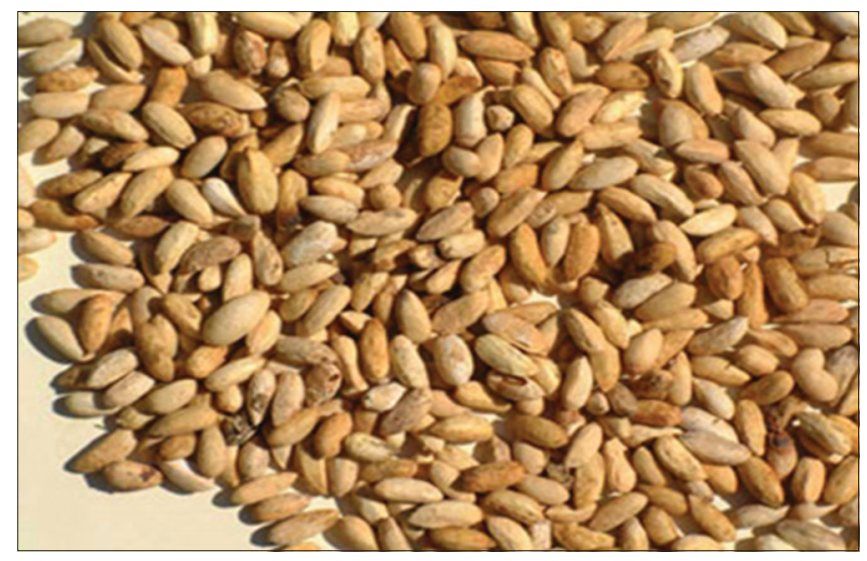

Figure 2: Neem seed kernel

filtration process. Neem extract was stored in transparent bottle as shown in Figure 3

\section{Mixing of $\mathrm{CaOH}$ (lime) and Neem Extract}

$\mathrm{CaOH}$ (lime) and Neem Extract was partially dissolved and releases hydroxyl anions (OH-) in solution. A suspension of fine calcium hydroxide particles in water is called milk of lime. The solution was called lime water. The mixture of neem aqueous extract (Figure 4) and $\mathrm{CaOH}_{2}$ called indigenous mixture.

\section{Preparation of Indigenous (Neem Lime) balls}

Indigenous mixture (Neem aqueous extract and $\mathrm{CaOH}$ ) was contained in a glass jar and ready for making of small balls. Small balls of $2 \mathrm{~cm}$ diameter were made by hand rolling method. 25 balls were prepared and dried in sun light for $12 \mathrm{~h}$. Weight of each ball was $15 \mathrm{~g}$. After sun drying the balls were hard and were ready to use as shown in Figure 5

\section{Neem-Lime Balls In Paddy Storage}

For storage study, we were taken 12 kg paddy (variety Pusa-1544) which was received from Directorate, seed processing plant, Sam Higginbottom University of Agriculture Technology and Sciences, Allahabad. 12 Gunny bags were purchased from the

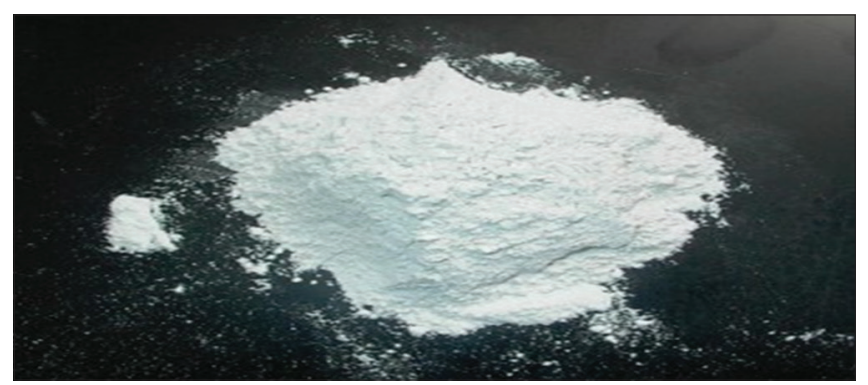

Figure 3: Cacium hydroxide $(\mathrm{CaOH})$

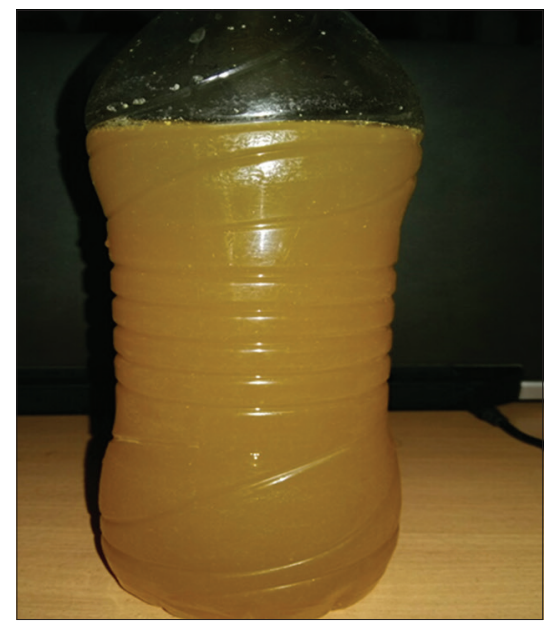

Figure 4: Neem leaf extract

local market to hold $1 \mathrm{~kg}$ paddy. The moisture content of paddy was measured by digital moisture meter. 1 ball was kept in each of 3 samples (sample noted as T11, T21, and T31 respectively). 2 balls were kept in each of 3 samples (sample noted as T12, T22, and T32 respectively). 3 balls were kept in each of three samples. These 12 samples were placed in warehouse at seed research farm as shown in Figure 6.

\section{RESULTS AND DISCUSSION}

In this study, the results pertaining to evaluation of "Effect of Neem extract and Calcium Hydroxide $(\mathrm{CaOH})$ on paddy during storage" are presented and analyzed. The results are presented under the following headings.

\section{Effect of Different Levels of CaoH and Neem on Paddy during Storage}

\section{Moisture Content}

The moisture content of paddy stored with 1 ball (sample T1) on $0^{\text {th }}$ day was $12.5 \%$ w.b. whereas with 2 balls (T2) it was $12.8 \%$ w.b. and with 3 balls (sample T3) it was $12.6 \%$ w.b. The moisture content after 5 days storage was $12.5 \%$ in both sample T20 and $\mathrm{T} 30$ whereas it was $12.2 \%$ for sample T3. The results are shown in table 1. It is evident that there was decrease in moisture content during storage. The study shows the results as increased in number of balls with decrease in moisture content. Similar 


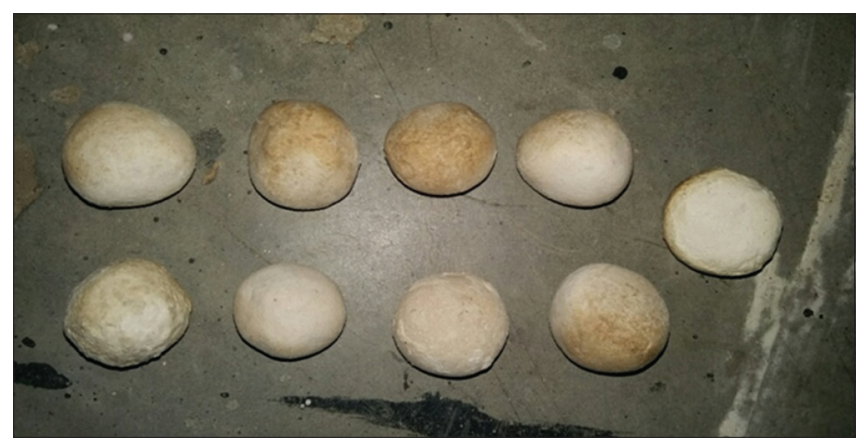

Figure 5: Balls of Indigenous mixture
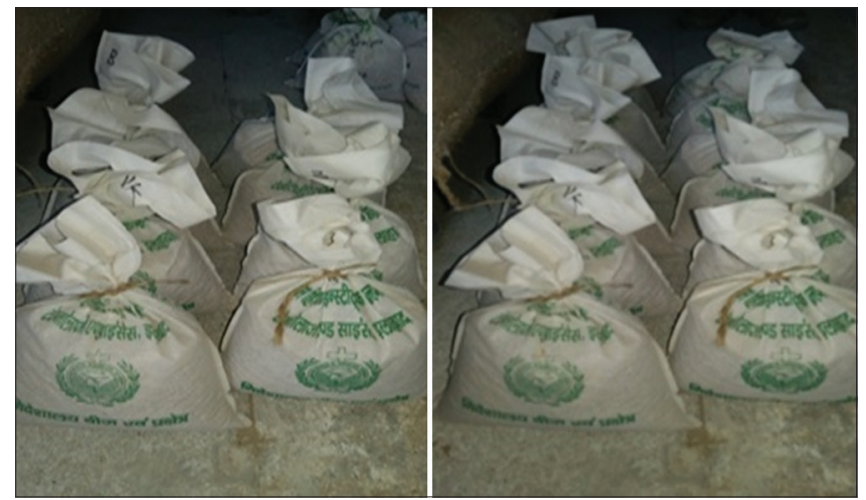

Figure 6: Paddy samples with balls

results were obtained for wheat in study of bacterial growth in wheat [7]. During storage, moisture loss takes place because $\mathrm{CaOH}$ absorbs the moisture content in paddy.

\section{Weight Loss}

The weight of paddy stored with 1 ball (sample $\mathrm{Tl}$ ) $\mathrm{CaOH}$ and Neem on $0^{\text {th }}$ day was $1000 \mathrm{~g}$ in all treatments. The result is shown in table 2. It shows that there was a decrease in weight during storage. During storage, weight loss takes place because calcium hydroxide absorbs the moisture of grain and paddy losses the weight during storage due to climatic factors.

\section{Seed Viability Percentage}

The viability percentage of paddy stored with 1 ball (sample $\mathrm{T} 1$ ) on $0^{\text {th }}$ day was $90 \%$ whereas with 2 balls (sample T2) and 3 balls (sample T3) same as $90 \%$. The result is shown in table 3 . During storage change in viability takes place because Neem prevents the seed from fungus and bacteria and other seed damaging factors.

The neem protects are found to be effective against the pest during paddy storage and its cheaper and easily available source as compare to other sources, apart from already reported uses
Table 1: Moisture content (\%) on w.b. of paddy during storage

\begin{tabular}{llccc}
\hline Sr. No. & Treatments & $0^{\text {th }}$ day (\%) & $5^{\text {th }}$ day (\%) & $1^{\text {th }}$ day (\%) \\
\hline 1 & $\mathrm{~T}_{10}$ & 12.5 & 12.4 & 12.4 \\
2 & $\mathrm{~T}^{1}$ & 12.5 & 12.3 & 12.3 \\
3 & $\mathrm{~T}^{20}$ & 12.5 & 12.5 & 12.5 \\
4 & $\mathrm{~T}_{2}$ & 12.5 & 12.3 & 12.2 \\
5 & $\mathrm{~T}_{30}^{30}$ & 12.5 & 12.5 & 12.4 \\
6 & $\mathrm{~T}_{3}$ & 12.5 & 12.2 & 12.2 \\
\hline
\end{tabular}

Table 2: Weight (g) of paddy during storage

\begin{tabular}{llccc}
\hline Sr. No. & Treatments & $0^{\text {th }}$ day $(\mathrm{g})$ & $5^{\text {th }}$ day $(\mathrm{g})$ & $10^{\text {th }}$ day $(\mathrm{g})$ \\
\hline 1 & $\mathrm{~T}_{10}$ & 1000 & 1000 & 990 \\
2 & $\mathrm{~T}_{1}$ & 1000 & 995 & 990 \\
3 & $\mathrm{~T}_{20}$ & 1000 & 1000 & 985 \\
4 & $\mathrm{~T}_{2}$ & 1000 & 990 & 990 \\
5 & $\mathrm{~T}_{30}$ & 1000 & 1000 & 990 \\
6 & $\mathrm{~T}_{3}$ & 1000 & 990 & 985 \\
\hline
\end{tabular}

Table 3: Viability of paddy during storage

\begin{tabular}{llccc}
\hline Sr. No. & Treatments & $0^{\text {th }}$ day $(\mathrm{g})$ & $5^{\text {th }}$ day $(\mathrm{g})$ & $1^{\text {th }}$ day $(\mathrm{g})$ \\
\hline 1 & $\mathrm{~T}_{10}$ & 90 & 88 & 88 \\
2 & $\mathrm{~T}_{1}$ & 90 & 89 & 89 \\
3 & $\mathrm{~T}_{20}$ & 90 & 89 & 90 \\
4 & $\mathrm{~T}_{2}$ & 90 & 89 & 88 \\
5 & $\mathrm{~T}_{30}$ & 90 & 87 & 87 \\
6 & $\mathrm{~T}_{3}$ & 90 & 90 & 90 \\
\hline
\end{tabular}

of neem [8]. The research was aimed to determine the effect of $\mathrm{CaOH}$ and Neem leaf extract on paddy during storage. In this research the paddy samples are treated with Neem lime balls (indigenous mixture).

According to study and observations, It is concluded that Neem Lime balls are very effective for paddy storage. It is a cheaper and easily available source for post harvest management of paddy. Anybody easily adopt this storage technique of paddy by using Neem which is fully organic in nature and there is no side effect of neem as compare to other storage pesticides.

\section{REFERENCES}

1. Ministry of Agriculture (GOI) Annual report, 2014-15.

2. Indian Council of agriculture Research annual report, 2013.

3. Food and Agriculture Organisation financial report, 2011.

4. Girish K. Agricultural use of neem, Electronic Journal of Biology, 2008; 4(3):102-111.

5. Achio S., Ameko E. Insecticidal effect of Neem, International Journal of Research In BioSciences, 2012;2, 11-19.

6. Channamma Nanjayyanamath. Traditional storage structure book of storage of grain, University of Agricultural Sciences, Dharwad, 2004.

7. Berbert, P. A and B. C. Stenning. On-line water content measurement of wheat. Journal of Agricultural Engineering Research 1996; 65(4):287-296.

8. Subbalakshmi Lokanadhan, P. Muthukrishnan and S.Jeyaraman* Neem products and their agricultural applications, Journal of Biopesticides, 2012, 72-76. 